\title{
Growth performance, and carcass and meat quality traits in progeny of Poll Nellore, Angus and Brahman sires under tropical conditions
}

\author{
A. S. C. Pereira ${ }^{\mathrm{E}, \mathrm{I}}$, F. Baldi ${ }^{\mathrm{G}}$, R. D. Sainz ${ }^{\mathrm{A}}$, B. L. Utembergue ${ }^{\mathrm{H}}$, H. L. J. Chiaia ${ }^{\mathrm{G}}$, \\ C. U. Magnabosco ${ }^{\mathrm{B}}$, F. R. Manicardi ${ }^{\mathrm{C}}$, F. R. C. Araujo ${ }^{\mathrm{D}}$, C. F. Guedes ${ }^{\mathrm{E}}$, R. C. Margarido ${ }^{\mathrm{F}}$, \\ P. R. Leme ${ }^{\mathrm{E}}$ and P. J. A. Sobral ${ }^{\mathrm{E}}$ \\ ADepartment of Animal Science, University of California, Davis, CA 95616, USA. \\ ${ }^{B}$ Embrapa Cerrados, Planaltina - DF, Brazil. \\ ${ }^{\mathrm{C}}$ Guaporé Pecuária - Pontes e Lacerda - MT, Brazil. \\ ${ }^{D}$ Aval Serviços Tecnológicos, Uberaba - MG, Brazil. \\ ${ }^{E}$ Faculty of Animal Science and Food Engineering, University of São Paulo, Pirassununga - SP, Brazil. \\ FUsina Vale do Rosário, Orlândia - SP, Brazil. \\ GDepartment of Animal Science, São Paulo State University (FCAV/UNESP), Jaboticabal, SP, Brazil. \\ ${ }^{H}$ Department of Animal Production and Nutrition, Faculty of Veterinary Medicine and Animal Science, \\ University of São Paulo, Pirassununga, SP, Brazil. \\ 'Corresponding author. Email: angelpereira@usp.br
}

\begin{abstract}
This study aimed to characterise progeny of sires representing major families in the Poll Nellore breed. Fourteen Poll Nellore sires, two Angus sires and one Brahman sire were mated by AI to $~ 400$ multiparous Poll Nellore dams. Calves were raised and stocked on pasture in central Brazil until reaching $\sim 18$ months of age, then fed a sugarcane bagasse-based diet on an ad libitum basis until reaching market weight and finish (average 23 months). There were 236 Poll Nellore (N), 38 Angus $\times$ Poll Nellore $(\mathrm{AN})$ and 31 Brahman $\times$ Poll Nellore $(\mathrm{BN})$ calves born in total. The weaning and 423-day weight weights, and growth rates and pre- and post-weaning were greater $(P<0.05)$ in males than in female calves, and were influenced by breed and by sire within the $\mathrm{N}$ animals. The weaning weights were higher $(P<0.05)$ in $\mathrm{AN}$ and $\mathrm{BN}$ than in $\mathrm{N}$ calves. The 423-day weight weights were greater $(P<0.05)$ in AN calves, followed by BN, with straightbred $\mathrm{N}$ being lightest. Feedlot average daily gain was unaffected $(P>0.05)$ by sex or by sire within $\mathrm{N}$, but was lowest $(P<0.05)$ in $\mathrm{N}$ cattle, and highest in AN and BN animals, which did not differ $(P>0.05)$. Heifers reached the end of the study with lower bodyweight (BW) and dressing percentage than steers, resulting in lower carcass weights, smaller longissimus muscle areas (LMA), but greater 12th to 13th rib backfat (BF) and similar marbling score and mean shear force. However, the proportion of carcasses grading Choice or Prime was numerically greater in heifers than in steers $(23.6 \% \mathrm{vs} 9.8 \%)$. AN cattle reached greater harvest weights than $\mathrm{BN}$, and those were heavier than $\mathrm{N}$ cattle $(P<0.001)$. However, dressing percentages were lowest in AN animals, so that there was no significant difference in carcass weight between AN and BN cattle. AN carcasses also had greater LMA, BF and marbling scores than the $\mathrm{N}$ carcasses. The proportion of carcasses grading Choice or Prime was numerically greater in $\mathrm{AN}$ cattle than in the BN and $\mathrm{N}$ groups $(25.9 \%, 11.8 \%$ and $15.9 \%$, respectively). Steaks from AN calves were more tender than $\mathrm{N}$ steaks, with the BN steaks being intermediate. There was significant variation among $\mathrm{N}$ sires for final BW, dressing percentage, carcass weight, LMA and marbling score, but not for BF or mean shear force. The percentages of carcasses of $\mathrm{N}$ cattle grading Choice or Prime ranged from $0 \%$ to $61.5 \%$. Three $\mathrm{N}$ sires produced progeny with greater than $40 \%$ of carcasses grading Choice or above (Berílio OB, Furador OB, and Litoral OB). Likewise, three N sires (Blitz OB, Furador OB and Sossego OB) had progeny with $67 \%, 62 \%$ and $75 \%$, respectively, of steaks classified as tender. This study confirmed that Zebu cattle have inferior carcass and meat quality relative to AN crossbreds under tropical conditions, however there is substantial variation within the $\mathrm{N}$ breed for these traits, and several sires have a proportion of their progeny comparable in terms of meat tenderness to those of Angus sires.
\end{abstract}

Additional keywords: carcass, cattle, crossbreeding, growth, meat quality, Poll Nellore.

Received 26 November 2013, accepted 2 September 2014, published online 24 December 2014

\section{Introduction}

To date, there is a tendency to value differentiated meat products (i.e. value-added products), in terms of meat organoleptic traits and consequences of meat consumption on human health. Recently, Brazil has become the world's largest beef exporter by volume, achieving 1.24 million tonnes in 2012 (ANUALPEC 
2012). This has been largely due to expansion of grazing into the central Cerrado (tropical savannah) region, made possible by use of cattle breeds that are well adapted to tropical conditions. The Nellore breed stands out as the dominant beef cattle breed, making up $\sim 80 \%$ of the roughly 200 million head in the national herd (ANUALPEC 2012). Therefore, a better understanding of the productive and quality potential of this breed is a priority for research.

The results obtained from the Germplasm Evaluation Program held at the Meat Animal Research Centre, where different beef cattle breeds were evaluated for various economic importance traits (Cundiff 2004), pointed out that, despite the Zebu (Nellore and Brahman) and their crosses (Brangus) demonstrating greater adaptation to the environment and resistance to parasites, they produced carcasses with less fat/lean ratio, lower meat tenderness and lower percentage of intramuscular fat than Bos taurus breeds. The genetic variation in both quantity and quality of beef is evident through differences between breeds and crossbreeds and between sires within a breed. Within-breed variation includes additive genetic effects and also the correlated impacts of additive genetic effects on other economically important productive and adaptive traits that affect beef production (Burrow et al. 2001). In most Brazilian Nellore breeding programs, the selection for meat and carcass traits is still limited, probably due to the difficulties and costs for obtaining them, since they are measured post mortem. In Brazil, there are few studies conducted with Bos indicus for carcass and meat traits. In this sense, Baldi et al. (2013) and Ferriani et al. (2013) concluded that these traits have genetic variation and should respond to selection.

Among the factors that define the carcass quality, the proportion of valuable meat cuts, and the percentage of fat (subcutaneous and intramuscular) on carcass and meat tenderness are important factors to be considered (Boleman et al. 1998). The meat produced from Zebu breeds in Brazil has organoleptic characteristics that are not well accepted in most demanding markets (Buainain and Batalha 2007). The Brazilian beef breeders are faced with the challenge of using vastly diverse production environments and systems to produce cattle that are both productive and profitable, and beef products that satisfy consumer requirements. Results from tropical and subtropical environments comparing breeds and crossbreds for carcass and meat quality traits are scarce (Schutt et al. 2009a, 2009b). Thus, this study aimed to characterise progeny of sires representing several major families in the Poll Nellore breed. In addition, these animals were compared with $\mathrm{F}_{1}$ Angus $\times$ Poll Nellore and Brahman $\times$ Poll Nellore crosses. The studied traits were preand post-weaning gains, fat development, and carcass and meat quality.

\section{Materials and methods}

\section{Animals and management}

A total of 14 sires representing seven major families within the Poll Nellore breed were selected from the Germplasm Bank of the Guaporé farm, located at the Pontes de Lacerdacounty, Mato Grosso state, Brazil. These sires were considered to represent a major family if the common ancestor appeared at least three times in the pedigree going back three generations. The Poll Nellore sires, along with two Angus sires (GT Encore and
Famous Players) and one Brahman sire (Mr V8 444/4) were mated by artificial insemination to $\sim 400$ multiparous commercial Poll Nellore dams. The Angus and Brahman sires were included to enable comparisons with breeds of known carcass and meat traits. The number of progeny per breed was 237 (114 females and 123 males), 38 (15 females and 23 males) and 31 (19 females and 12 males) for Poll Nellore, Brahman and Angus sires, respectively.

All calves were raised on pasture with their dams until $\sim 8$ months of age, then weaned and stocked on pasture on the same ranch (Fazenda Guaporé; Pontes e Lacerda, MT, Brazil) until reaching $\sim 18$ months of age. Male calves were castrated at 15 months. At 18 months of age, animals were transported to a feedlot at a sugarcane ethanol plant (Usina Vale do Rosário, Orlândia, SP, Brazil). The animals were fed ad libitum a bagassebased diet (Table 1), and remained in the feedlot for a period of 127 days until they reached $\sim 5 \mathrm{~mm}$ of subcutaneous fat thickness between the 12 th and 13 th ribs.

During the feedlot phase, five weighing records were measured. To perform the weighing, the animals were fasted for $12 \mathrm{~h}$. Research protocols followed the guidelines stated in the Guide for the Care and Use of Agricultural Animals in Agricultural Research and Teaching.

\section{Carcass and meat traits}

The animals were slaughtered between 22 and 24 months of age, at the Bertin Co. packing plant in Lins, SP, Brazil. At slaughter, carcasses were evaluated according to the company's internal standards as well as USDA grading standards (USDA 1999). After slaughter, the carcasses were weighed (hot carcass weight: $\mathrm{HCW}$ ), and remained inside the cooling chamber at $0-2^{\circ} \mathrm{C}$ for $24 \mathrm{~h}$. These measures were used to obtain the carcass yielding, percentage of $\mathrm{HCW}$ in relation to bodyweight $(\mathrm{BW})$. Additional measurements including temperature and $\mathrm{pH}$ were taken in the Longissimus dorsi muscle in the hanging carcass. Twenty-four

Table 1. Ingredients, chemical and nutritional composition of diet utilised in the feedlot on a dry matter basis ${ }^{\mathrm{A}}$

\begin{tabular}{lc}
\hline Ingredients & \% of DM \\
\hline Cracked corn & 35.2 \\
Soybean hulls & 20.0 \\
Hydrolised sugarcane bagasse & 13.4 \\
Sugarcane bagasse & 10.0 \\
Yeast & 10.0 \\
Soybean meal (45\% crude protein) & 6.0 \\
Molasses & 2.5 \\
Trace mineralised salt & 2.3 \\
Urea & 0.6 \\
Rumensin & 0.027 \\
& \\
Crude protein (\% DM) & Estimated composition \\
Rumen-degradable protein (\% DM) & 14.2 \\
Total digestible nutrients (\% DM) & 8.3 \\
NE ${ }_{\mathrm{m}}$ (Mcal/kg DM) & 71.2 \\
NE (Mcal/kg DM) & 1.67 \\
Calcium (\% DM) & 1.06 \\
Phosphorus (\% DM) & 0.49 \\
\hline
\end{tabular}

\footnotetext{
${ }^{\mathrm{A}}$ The moisture content of the diet was $85 \%$.
} 
hours post mortem, samples from the Longissimus dorsi muscle were taken between the 10th and 13th ribs, vacuum-packed then aged for 14 days at $1{ }^{\circ} \mathrm{C}$ before being frozen at $-20^{\circ} \mathrm{C}$ pending analyses. These analyses included:

- Water loss by exudation (WLE): initially, the water loss by exudation of Longissimus dorsi $[\mathrm{WLE}=\mathrm{We} /(\mathrm{We}+\mathrm{Wb})] \times$ 100 ; was calculated by weighing the steak $(\mathrm{Wb})$ and exudate (We). The values were expressed as percentages.

- Cooking weight losses (CWL): the cooking weight losses was determined by the weight difference before and after baking $[\mathrm{CWL}=(\mathrm{Wi}-\mathrm{Wf}) / \mathrm{Pi}]$ by weighing initial steak $(\mathrm{Wi})$ and the final weighing (Wf), expressed as a percentage. All weighings were performed with the semi-analytical scale (Honikel 1998). Steaks for cooking loss and shear force were chilled overnight at $4^{\circ} \mathrm{C}$. The initial weight of the steaks was on average $125 \mathrm{~g}$ approximate. The time and temperature of the cooking were $\sim 15$ min until the internal temperature reached $71^{\circ} \mathrm{C}$ in the steak.

- Tenderness: after weighing the samples, individual thermometers were inserted by drilling, reaching the geometric centre of the samples. The meat tenderness was measured according to the method given by Wheeler et al. (2001), using the Warner-Bratzler shear force equipment. The mean shear of each sample was considered as the average values of six cylinders. The six cylinders $(1.27 \mathrm{~cm}$ diameter $)$ were obtained from each steak parallel to the longitudinal orientation of the muscle fibres.

The percentage of carcasses with shear forces above $3.9 \mathrm{~kg}$ was calculated for each progeny group, as this value was shown to be a cut-off for slightly tender steaks (Shackelford et al. 1991).

\section{Statistical analyses}

The animals were divided in blocks according to the initial weight during the feedlot phase. The experimental design was randomised blocks in a $3 \times 2$ factorial arrangement (breed $\times$ sex). To compare the genetic groups, the fixed effects of genotype (genetic group), sex, genotype* sex interaction, block and age at slaughter as a linear covariable (only for meat and carcass traits), were considered in the model. For weaning weight, 423-day weight, 423-day scrotal circumference (SC), and weight gains during the post-weaning and feedlot phases, and the age of the animal at measurement was added in the model as a covariable (linear and quadratic effect). A factorial arrangement $14 \times 2$ (bulls $\times$ sex) was used for the analysis of differences between Poll Nellore sire group. The data were analysed by variance analyses using the PROC GLM procedure (SAS Institute, Cary, NC, USA) at $5 \%$ significance level. The means were compared by the Bonferroni test at the level of 5\% significance. In the presence of significant interaction $(P<0.05)$ between the factors, the means for each breed were compared within sex by Bonferroni test at 5\% significance level.

\section{Results and discussion}

\section{Growth traits}

There were 236 Poll Nellore $(\mathrm{N}), 38$ Angus $\times$ Poll Nellore (AN) and 31 Brahman $\times$ Poll Nellore $(\mathrm{BN})$ calves born in total. The pre-weaning growth was influenced $(P<0.05)$ by sex and genetic group (Table 2). The interaction between sex and genetic group was not significant $(P>0.05)$ for pre- and post-
Table 2. Least square means and standard error (between parentheses) for weaning weight (WW), 423-day weight (YW) and 423-day scrotal circumference (SC), and weight gains (kg/day) during the post-weaning and feedlot phases of progeny of Angus, Brahman and Poll Nellore sires a,b: means in the same row with no letters or a common letter do not differ significantly $(P<0.05)$. x,y,z: means in the same column with no letter or a common letter do not differ significantly $(P<0.05)$

\begin{tabular}{|c|c|c|c|c|}
\hline \multicolumn{5}{|c|}{$\mathrm{WW}(\mathrm{kg})^{\mathrm{A}}$} \\
\hline \multirow[t]{2}{*}{ Sire breed } & \multicolumn{3}{|c|}{ Gender } & Mean \\
\hline & \multicolumn{2}{|c|}{ Females } & Males & \\
\hline Angus & \multicolumn{2}{|c|}{$204(n=19)^{\mathrm{E}}$} & $217(n=12)$ & $210(3.91) \mathrm{x}$ \\
\hline Brahman & \multicolumn{2}{|c|}{$198(n=15)$} & $217(n=23)$ & $208(4.0) \mathrm{x}$ \\
\hline Poll Nellore & \multicolumn{2}{|c|}{$176(n=114)$} & $197(n=123)$ & $186(1.50) y$ \\
\hline \multirow[t]{2}{*}{ Mean } & $192(2$. & 66)b & $210(2.80) \mathrm{a}$ & \\
\hline & \multicolumn{3}{|c|}{ YW $(\mathrm{kg})^{\mathrm{B}}$} & $\mathrm{SC}(\mathrm{cm})^{\mathrm{B}}$ \\
\hline \multirow[t]{2}{*}{ Sire breed } & \multicolumn{2}{|c|}{ Gender } & Mean & Mean \\
\hline & Females & Males & & \\
\hline Angus & 289 & 309 & $299(4.10) \mathrm{x}$ & $27.0(0.90) \mathrm{x}$ \\
\hline Brahman & 273 & 291 & $282(4.13) y$ & $23.3(0.96) y$ \\
\hline Poll Nellore & 231 & 267 & $249(1.60) \mathrm{z}$ & $22.2(0.81) y$ \\
\hline \multirow[t]{2}{*}{ Mean } & $265(2.80) \mathrm{b}$ & $289(2.88) \mathrm{a}$ & - & - \\
\hline & \multicolumn{3}{|c|}{$\begin{array}{l}\text { Post-weaning ADG } \\
(\mathrm{kg} / \text { day })^{\mathrm{C}, \mathrm{D}}\end{array}$} & $\begin{array}{c}\text { Feedlot ADG } \\
(\mathrm{kg} / \text { day })\end{array}$ \\
\hline \multirow[t]{2}{*}{ Sire breed } & \multicolumn{2}{|c|}{ Gender } & Mean & Mean \\
\hline & Females & Males & & \\
\hline Angus & 0.538 & 0.591 & $0.565(0.014) \mathrm{x}$ & $1.304(0.03) \mathrm{x}$ \\
\hline Brahman & 0.414 & 0.454 & $0.434(0.014) y$ & $1.205(0.03) \mathrm{x}$ \\
\hline Poll Nellore & 0.352 & 0.440 & $0.396(0.005) y$ & $1.067(0.01) \mathrm{y}$ \\
\hline Mean & $0.435(0.01) \mathrm{b}$ & $0.495(0.01) \mathrm{a}$ & - & - \\
\hline
\end{tabular}

${ }^{\mathrm{A}}$ Means are adjusted to a common age (260 days) by ANCOVA.

${ }^{\mathrm{B}}$ Means are adjusted to a common age ( 423 days) by ANCOVA.

${ }^{\mathrm{C}}$ Means are adjusted to a common age (423 days) by ANCOVA.

${ }^{\mathrm{D}}$ Average daily gain from weaning to entry to the feedlot at $\sim 18$ months of age.

${ }^{\mathrm{E}}$ Number of progeny per sire.

weaning growth traits. Male calves had higher weaning weights $(+10 \%)$ than in females calves, and in AN and BN than $\mathrm{N}$ calves $(+13 \%$, Table 3$)$. This superiority of Bos taurus $\times$ Bos indicus calves over straightbred Bos indicus calves is in agreement with previous studies (Brown et al. 1993; Riley et al. 2007). Comparisons between Bos indicus $\times$ Bos taurus calves and straightbred Bos taurus calves have been less consistent, with some studies showing superiority (Gregory et al. 1979; Cundiff et al. 1998) and others no difference (Thallman et al. 1999; Lunstra and Cundiff 2003) between crossbreds and straightbreds at weaning. Therefore, it is likely that the greater weaning weights of $\mathrm{AN}$ and $\mathrm{BN}$ (relative to $\mathrm{N}$ ) calves in this study were at least partly due to individual heterosis and breed differences. There were no significant differences in weaning weights among progeny of $\mathrm{N}$ bulls.

The 423-day weight weights were heavier $(P<0.05)$ in AN calves, followed by $\mathrm{BN}$, with straightbred $\mathrm{N}$ being lighter than the other groups (Table 3). These differences in BW reflected greater $(P<0.05)$ average daily gain (ADG) in AN calves, compared with $\mathrm{BN}$ and $\mathrm{N}$ calves, which had similar postweaning gains $(P>0.05$; Table 3$)$. This superiority in postweaning ADG and 15 -months weight of Bos taurus $\times$ Bos indicus 
calves over straightbred Bos indicus calves confirms previous studies (Brown et al. 1993; Newman et al. 2002).

Within the $\mathrm{N}$ calves, there were no differences $(P>0.05)$ among progeny of different bulls for weight and ADG until 15 months of age (Table 3 ). In all genetic groups, males were heavier than females $(+25 \mathrm{~kg}, P<0.05)$. Male calves sired by Angus bulls had greater $(P<0.05)$ SC at 423 days of age than

Table 3. Least square means for weight gains (kg/day) of progeny of Poll Nellore sires and Poll Nellore dams during the post-weaning and feedlot phases ${ }^{A}$

\begin{tabular}{lcc}
\hline Sire & $\begin{array}{c}\text { Post-weaning } \\
\text { ADG }(\mathrm{kg} / \text { day })^{\mathrm{B}}\end{array}$ & $\begin{array}{c}\text { Feedlot } \\
\text { ADG }(\mathrm{kg} / \text { day })\end{array}$ \\
\hline Berílio $(n=12)^{\mathrm{C}}$ & 0.371 & 1.083 \\
Blitz $(n=18)$ & 0.406 & 1.073 \\
Dalamu $(n=22)$ & 0.374 & 1.121 \\
Dólar $(n=22)$ & 0.399 & 1.027 \\
Furador $(n=13)$ & 0.405 & 0.945 \\
Itaú $(n=22)$ & 0.398 & 1.144 \\
Laiko $(n=22)$ & 0.377 & 0.993 \\
Litoral $(n=9)$ & 0.436 & 1.154 \\
Modello $(n=22)$ & 0.400 & 1.031 \\
Pagode $(n=25)$ & 0.425 & 1.130 \\
Plato $(n=20)$ & 0.425 & 1.079 \\
Sanduíche $(n=4)$ & 0.298 & 0.889 \\
Simpático $(n=18)$ & 0.388 & 1.070 \\
Sossego $(n=8)$ & 0.338 & 1.054 \\
Overall $P$-value & 0.88 & 0.06 \\
Pooled s.e.m. value & 0.15 & 0.27 \\
\hline A Means are a & &
\end{tabular}

${ }^{\mathrm{A}}$ Means are adjusted to a common age (423 days) by ANCOVA.

${ }^{\mathrm{B}}$ Average daily gain from weaning to entry to the feedlot at $\sim 18$ month of age.

${ }^{\mathrm{C}}$ Number of progeny per sire. calves sired by Poll Nellore and Brahman bulls, which were not different from each other (Table 2). The selection for higher SC would increase the female sexual precocity (MartínezVelázquez et al. 2003; Forni and Albuquerque 2005) in Bos taurus and Bos indicus breeds. Therefore, as stated more than 25 years ago (Turner 1980; Dow et al. 1982), Zebu cattle are later-maturing than Bos taurus and crossbreds. There were no differences $(P>0.05)$ in SC among progeny of Poll Nellore sires (data not shown).

As shown in Fig. 1, animals entered their second dry season while still on pasture, and growth was essentially zero during this time.

Upon placement in the feedlot, growth rate accelerated to an average ADG of $1.113 \mathrm{~kg} /$ day. The feedlot ADG was unaffected $(P>0.05)$ by sex, but was lowest $(P<0.05)$ in $\mathrm{N}$ cattle, and highest in AN and BN animals, which did not differ $(P>0.05$; Table 2). Similarly, Ribeiro et al. (2005) compared ADG in steers finished on Brachiaria (Guinea grass) pasture and also found no difference between BN and N steers. Moreover, Paschal et al. (1995) found that Brahman $\times$ Hereford, Poll Nellore $\times$ Hereford and Angus $\times$ Hereford steers had similar feedlot ADG. By contrast, Gregory et al. (1979) and Huffman et al. (1990) found that Brahman crossbreds had greater feedlot ADG than straightbred (Angus) or crossbred (Angus $\times$ Hereford) Bos taurus steers, suggesting a strong effect of heterosis. Similarly to post-weaning weight gains, feedlot weight gains were not different $(P>0.05)$ among progeny of Poll Nellore sires (Table 3).

\section{Carcass and meat quality traits}

The differences between females and castrated males with regard to carcass and meat traits are shown in Table 4. Heifers



Fig. 1. Evolution of least square means for age-adjusted weights from birth to slaughter for progeny of Angus, Brahman and Poll Nellore sires. The birthweights were adjusted to an age of zero. 
Table 4. Effects of sire breed and sex on carcass and meat quality traits ${ }^{\mathrm{A}}$

\begin{tabular}{|c|c|c|c|c|c|c|c|c|c|}
\hline \multirow[t]{2}{*}{ Trait } & \multicolumn{5}{|c|}{ Sire breed } & \multicolumn{4}{|c|}{ Gender } \\
\hline & Angus & Brahman & Poll Nellore & s.e.m. ${ }^{\text {B }}$ & $P^{\mathrm{C}}$ & Heifers & Steers & s.e.m. & $P$ \\
\hline Final BW (kg) & $507 \mathrm{a}$ & $469 b$ & $413 c$ & 6.10 & $<0.001$ & $440 \mathrm{~b}$ & $479 \mathrm{a}$ & 5.89 & $<0.001$ \\
\hline Hot carcass weight $(\mathrm{kg})$ & $274 a$ & $262 \mathrm{a}$ & $232 b$ & 3.38 & $<0.001$ & $242 b$ & $270 \mathrm{a}$ & 3.26 & $<0.001$ \\
\hline Longissimus muscle area $\left(\mathrm{cm}^{2}\right)$ & $65.6 \mathrm{a}$ & $60.2 b$ & $56.5 \mathrm{c}$ & 0.97 & $<0.001$ & $58.5 \mathrm{~b}$ & $63.1 \mathrm{a}$ & 0.93 & $<0.001$ \\
\hline 12 th rib fat thickness $(\mathrm{mm})$ & $8.6 \mathrm{a}$ & $7.3 \mathrm{ab}$ & $7.1 \mathrm{~b}$ & 0.58 & 0.035 & $9.0 \mathrm{a}$ & $6.3 \mathrm{~b}$ & 0.56 & $<0.001$ \\
\hline Marbling score ${ }^{\mathrm{D}}$ & 279 & 242 & 255 & 15.4 & 0.18 & 265 & 253 & 14.9 & 0.41 \\
\hline $\mathrm{pH}$ at $24 \mathrm{~h}$ & 5.70 & 5.73 & 5.72 & 0.018 & 0.49 & $5.66 \mathrm{~b}$ & $5.74 \mathrm{a}$ & 0.016 & 0.022 \\
\hline Cooking loss (\%) & 15.7 & 15.8 & 16.3 & 0.88 & 0.80 & 15.7 & 15.9 & 0.85 & 0.80 \\
\hline Drip loss (\%) & 3.9 & 4.1 & 4.4 & 0.43 & 0.43 & $2.7 \mathrm{~b}$ & $5.6 \mathrm{a}$ & 0.41 & $<0.001$ \\
\hline Warner-Bratzler shear force $(\mathrm{kg})$ & $3.30 \mathrm{~b}$ & 3.86ab & $4.15 \mathrm{a}$ & 0.27 & 0.016 & 3.63 & 3.91 & 0.26 & 0.29 \\
\hline$\%$ of carcasses with shear force $>3.9 \mathrm{~kg}$ & 25.9 & 41.2 & 46.6 & - & - & 30.7 & 41.8 & - & - \\
\hline
\end{tabular}

\footnotetext{
${ }^{\mathrm{A}}$ Values are least square means adjusted to a common age (23 months) by ANCOVA.

${ }^{\mathrm{B}}$ s.e.m., mean standard error.

${ }^{\mathrm{C}} P$, probability of a Type I error.

${ }^{\mathrm{D}}$ Marbling scores: $200=$ Select $^{0}, 300=$ Small $^{0}$.
}

reached the end of the study with lower BW and dressing percentage than steers, resulting in much lower carcass weights. Along with the lighter carcasses, heifers had smaller longissimus muscle areas (LMA) than steers; but they had greater 12th to 13th rib backfat (BF). Other differences included lower 24-h $\mathrm{pH}$ and drip loss in heifers as compared with steers. There was no difference $(P>0.05)$ between heifers and steers in mean marbling score, cooking loss and shear force, although heifers had a numerically smaller proportion of steaks above $3.9 \mathrm{~kg}$ (Table 4). Moreover, the proportion of carcasses grading Choice or Prime was numerically greater in heifers than in steers $(23.6 \%$ vs $9.8 \%$, Table 4$)$. These results are in partial agreement with those of Choat et al. (2006), who found that heifers had lighter carcasses, but similar LMA and $\mathrm{BF}$ to steers. In that study, heifers had greater marbling scores than steers; shear force was similar (at equal BF) or higher (at equal marbling) in heifers than steers (Choat et al. 2006).

Calves sired by Angus bulls reached higher slaughter weights than those sired by Brahman bulls, and those were heavier than $\mathrm{N}$ calves $(P<0.001$, Table 4$)$. However, dressing percentages were lowest in $\mathrm{AN}$ animals, so that there was no significant difference in carcass weight between $\mathrm{AN}$ and $\mathrm{BN}$ cattle. In previous studies, $\mathrm{BN}$ steers were heavier at slaughter than $\mathrm{NN}$ steers (Ribeiro et al. 2005), BN steers were heavier than N steers (Franke 1997). In those studies, carcass weights were similar between BN and N (Franke 1997; Ribeiro et al. 2005) steers, indicating that $\mathrm{NN}$ cattle had greater dressing percentages. Many previous reports have shown that Bos indicus cattle (and crossbreds) have greater dressing percentages than Bos taurus breeds (Menezes et al. 2007), probably due to smaller internal organs such as heart, lungs, liver and gastrointestinal tract (Menezes et al. 2007). The AN carcasses had greater LMA, $\mathrm{BF}$ and marbling scores than the Zebu carcasses. The lower BF and marbling of Bos indicus cattle compared with Bos taurus breeds is well known (Pringle et al. 1997; Wheeler et al. 2001; Newman et al. 2002). The proportion of carcasses grading Choice or Prime was numerically greater in AN cattle than in the $\mathrm{BN}$ and $\mathrm{N}$ groups $(25.9 \%, 11.8 \%$ and $15.9 \%$, respectively; Table 4), in agreement with the results of Wheeler et al. (2001).

Although the genetic groups had similar $\mathrm{pH}$ values, drip and cooking losses, the steaks from AN calves were more tender than $\mathrm{N}$ steaks, with the $\mathrm{BN}$ steaks being intermediate (Table 4). The percentage of steaks with shear forces above 3.9 $\mathrm{kg}$ (Shackelford et al. 1991) followed the same pattern. Similarly, many authors have reported that Bos indicus cattle (and crossbreeds) produce tougher meat than Bos taurus breeds (Shackelford et al. 1995; Pringle et al. 1997; Wheeler et al. 2001). This relative toughness of Zebu meat appears to be at least partly due to higher activity of calpastatin in the muscle of these breeds (Wheeler et al. 1990; Shackelford et al. 1991; Pringle et al. 1997) compared with Bos taurus breeds. Although $\mathrm{N}$ calves produced tougher meat on average than $\mathrm{AN}$ and $\mathrm{BN}$ animals, half of the loin steaks from these animals could be classified as tender (Shackelford et al. 1991). Although the number of crossbred animals was considerable and the results showed that crossbred animals had better carcass and meat quality attributes than the Poll Nellore, the comparisons need to be treated with caution when there was only a single Brahman-sire involved and only two Angus sires.

The results of carcass and meat quality traits for progeny of each bull within the Poll Nellore breed are presented in Table 5. There was considerable (and statistically significant) variation among sires for final $\mathrm{BW}$, dressing percentage, carcass weight, LMA and marbling score. These results are expected, since the heritability estimates for final $\mathrm{BW}$, carcass weight, LMA and BF in Brahman cattle were $0.59,0.57,0.50$ and 0.37 (Smith et al. 2007). There were no significant differences $(P>0.05)$ among sire progeny groups for $\mathrm{BF}, \mathrm{pH}$, cooking loss, drip loss or shear force. Even so, the mean shear force ranged from $3.45 \mathrm{~kg}$ to $4.87 \mathrm{~kg}$, and the percentage of steaks above $3.9 \mathrm{~kg}$ ranged from $24 \%$ to $83 \%$ among sires. The mean shear force obtained in this study for the Poll Nellore 


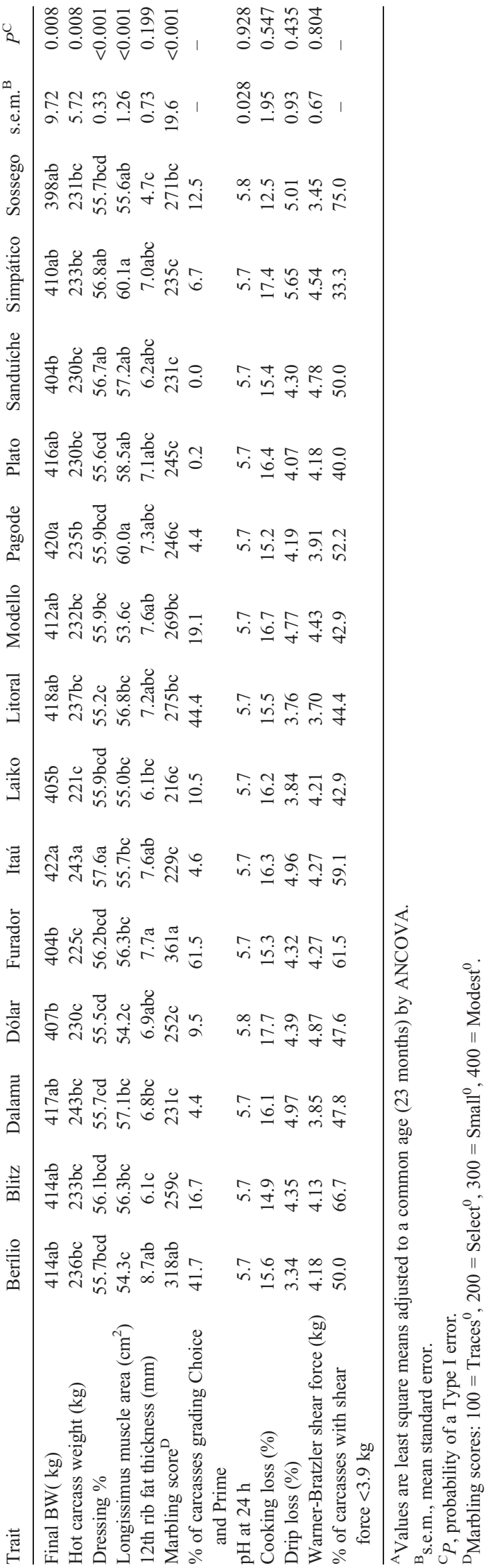

breed was lower than those reported by Burrow et al. (2001), Schutt et al. (2009b) and Pinto et al. (2010) also working with Zebu breeds. Probably, this lower mean value for shear force is explained by differences at slaughter age, genetic background and nutritional management. The Pearson correlation estimate between shear force and cooking losses was positive and moderate (0.71) indicating that tough meat is associated with higher cooking loss. In this sense, Silva et al. (1999) reported that the cooking loss and juiciness were related to the assessment of softness. It is known that a higher water retention capacity of the muscles contributes to the meat softness (Bouton et al. 1973). The percentages of carcasses of $\mathrm{N}$ cattle grading Choice or Prime ranged from $0 \%$ to $61.5 \%$. Admittedly, these values are based on very small sample sizes, but they suggest substantial genetic variability within this breed. It is worth noting that three Poll Nellore sires produced progeny with greater than $40 \%$ of carcasses grading Choice or above (including one Prime): Berílio OB, Furador OB, and Litoral OB. Likewise, three of the 14 Poll Nellore sires (Blitz OB, Furador OB and Sossego OB) had progeny with $67 \%, 62 \%$ and $75 \%$, respectively, of steaks classified as tender (i.e. with mean shear force less than $3.9 \mathrm{~kg}$ ).

The results of this study showed that crossbreeding is an effective tool to explore the effects of heterosis and complementarity between breeds. Burrow et al. (2001) reported that the effects of heterosis for carcass and meat traits were relatively small (3\% or less) compared with heterosis obtained for reproductive traits. These results are expected, since the carcass and meat traits have moderate to high heritability estimates. Despite heterosis effects not significantly improving carcass composition and meat quality, crossbreeding may indirectly improve these traits through higher growth rates, lower age at slaughter, as well as, by combining the desirable traits of each breed in a single individual (complementarity effect). Crossbred animals have greater weight and weight gains, and better carcass and meat quality attributes. The farmers should guide their matings in order to exploit the advantages of crossbreeding on carcass and meat traits, through crossbreeding systems or synthetic breeds, but also aim to maximise the benefits on reproductive traits, such as sexual precocity, longevity and/or cow mature size, which are important traits of the beef production system.

Finally, to take full advantages of crossbreeding it is also necessary have genetically evaluated animals, since crossbreeding and selection are complementary tools for genetic improvement. The results of this study demonstrated that there is considerable phenotypic variability for meat and carcass traits within the Poll Nellore breed. In these sense, Baldi et al. (2013) and Ferriani et al. (2013) working with Nellore concluded that these traits have enough phenotypic and genetic variation for response to selection. However, the meat and carcass traits have late expression, are difficult and expensive to measure, which hampers the availability of young animals evaluated for carcass and meat traits with reasonable accuracy. To overcome these difficulties, one possibility is the identification of genetic markers or polymorphisms in genes that influence carcass and meat traits to improve these traits through marker-assisted selection or genomic selection (Garrick 2011). 


\section{Conclusions}

This study confirms previous reports and much common knowledge regarding the advantages of $\mathrm{F}_{1}$ Bos taurus $\times$ Bos indicus over the straightbred Bos indicus breeds. Crossbreds have superior weight gains and on average produce heavier carcasses with superior fat cover and meat quality, than straightbred Zebu under tropical conditions. This is most likely due to a combination of the inherent superiority of the Angus breed for these traits, as well as heterosis effect.

The Zebu cattle had inferior carcass and meat quality relative to the AN crossbreds, as determined by marbling scores and shear force. This study, however, demonstrated that there is substantial variation within the Poll Nellore breed for these traits, and several sires have a proportion of their progeny comparable in terms of meat tenderness to those of Angus sires. To our knowledge this is the first report in which these observations have been made in a rigorous fashion using a known genetic base. These observations are merely phenotypic, but ongoing work is aimed at determining genetic and genomic components of this variation.

\section{Acknowledgement}

This study took several years to complete, and involved a large number of collaborators. In particular, the authors thank Guaporé Pecuária (Pontes e Lacerda, MT - Brazil), the private company that provided the animals and paid all the costs for their upkeep, as well as all the research expenses.

\section{References}

ANUALPEC (2012) 'Anuário da pecuária brasileira.' (FNP Consultoria \& Comércio: São Paulo) 400 pp.

Baldi F, Espigolan R, Oliveira HN, Souza FP, Gordo DG, Magalhães AFB, Albuquerque LG (2013) Genetic parameter estimates for carcass and meat traits in Poll Nellore cattle. In 'Fifty-ninth international congress of meat science and technology, 2013, Izmir'. (Elsevier: Amsterdam)

Boleman SL, Boleman SJ, Morgan WW, Hale DS, Griffin DB, Savell JW, Ames RP, Smith MT, Tatum JD, Field TG, Smith GC, Gardner BA, Morgan JB, Northcutt SL, Dolezal HG, Gill DR, Ray FK (1998) National Beef Quality Audit-1995: survey of producer-related defects and carcass quality and quantity attributes. Journal of Animal Science 76, 96-103.

Bouton PE, Carrol FD, Harris PV, Shorthose WR (1973) Influence of pH and fibre contraction state upon factors affecting the tenderness of bovine muscle. Journal of Food Science 38, 404-407. doi:10.1111/j.13652621.1973.tb01440.x

Brown MA, Brown AH Jr, Jackson WG, Miesner JR (1993) Genotype $\times$ environment interactions in postweaning performance to yearling in Angus, Brahman, and reciprocal-cross calves. Journal of Animal Science 71, 3273-3279.

Buainain AM, Batalha MO (2007) Cadeia Produtiva da Carne Bovina. Série de Agronegocios. Ministério da Agricultura, Pecuária e Abastecimento, Janeiro v. 8, Instituto Interamericano de Cooperaçãopara a Agricultura (IICA), Brasilia.

Burrow HM, Moore SS, Johnston DJ, Barendse W, Bindon BM (2001) Quantitative and molecular genetic influences on properties of beef: a review. Australian Journal of Experimental Agriculture 41, 893-919. doi:10.1071/EA00015

Choat WT, Paterson JA, Rainey BM, King MC, Smith GC, Belk KE, Lipsey RJ (2006) The effects of cattle sex on carcass characteristics and longissimus muscle palatability. Journal of Animal Science 84, 1820-1826. doi: $10.2527 /$ jas.2004-418
Cundiff LV (2004) Breeds and genetics. In 'Encyclopedia of animal science'. (Eds WG Pond, AW Bell) pp. 800-830. (Ithaca: Cornell)

Cundiff LV, Gregory KE, Koch RM (1998) Germplasm evaluation in beef cattle: Cycle IV: birth and weaning traits. Journal of Animal Science 76, 2528-2535.

Dow JS Jr, Moore JD, Bailey CM, Foote WD (1982) Onset of puberty in heifers of diverse beef breeds and crosses. Journal of Animal Science 55, 1041-1047.

Ferriani L, Albuquerque LG, Baldi F, Venturini G, Bignardi AB, Silva JAV, Chud TCS, Munari DP, Oliveira JA (2013) Parâmetros genéticos de características de carcaça e de crescimento de bovinos da raça Nelore. Archivos de Zootecnia 62, 123-129. doi:10.4321/S0004-05922013 000100013

Forni S, Albuquerque LG (2005) Estimates of genetic correlations between days to calving and reproductive and weight traits in Poll Nellore cattle. Journal of Animal Science 83, 1511-1515.

Franke DE (1997) Postweaning performance and carcass merit of F1 steers sired by Brahman and alternative subtropically adapted breeds. Journal of Animal Science 75, 2604-2608.

Garrick DJ (2011) The nature, scope and impact of genomic prediction in beef cattle in the United States. Genetics, Selection, Evolution. 43, 17. doi:10.1186/1297-9686-43-17

Gregory KE, Laster DB, Cundiff LV, Smith GM, Koch RM (1979) Characterization of biological types of cattle - Cycle III: II. Growth rate and puberty in females. Journal of Animal Science 49, 461-471.

Honikel KO (1998) Reference methods for the assessment of physical characteristics of meat. Meat Science 49, 447-457. doi:10.1016/S0309$1740(98) 00034-5$

Huffman RD, Williams SE, Hargrove DD, Johnson DD, Marshall TT (1990) Effects of percentage Brahman and Angus breeding, age-season of feeding and slaughter end point on feedlot performance and carcass characteristics. Journal of Animal Science 68, 2243-2252.

Lunstra DD, Cundiff LV (2003) Growth and pubertal development in Brahman-, Boran-, Tuli-, Belgian Blue-, Hereford- and Angus-sired F1 bulls. Journal of Animal Science 81, 1414-1426.

Martínez-Velázquez GK, Gregory E, Bennett GL, Van Vleck LD (2003) Genetic relationships between scrotal circumference and female reproductive traits. Journal of Animal Science 81, 395-401.

Menezes LFG, Restle J, Brondani IL, Kuss F, Alves Filho DC, da Silveira MF, Leite DT (2007) Internal organs and gastrointestinal tract of feedlot finished steers of advanced generations of rotational crossbreeding between Charolais and Poll Nellore. Revista Brasileira de Zootecnia 36, 120-129. doi:10.1590/S1516-35982007000100015

Newman S, Reverter A, Johnston DJ (2002) Purebred-crossbred performance and genetic evaluation of postweaning growth and carcass traits in Bos indicus $\times$ Bos taurus crosses in Australia. Journal of Animal Science $\mathbf{8 0}$, $1801-1808$.

Paschal JC, Sanders JO, Herr JL, Lunts DK, Herring AD (1995) Postweaning and feedlot growth and carcass characteristics of Angus-, Gray Brahman-, Gir-, Indu-Brazil-, Poll Nellore-, and Red Brahman-sired F1 calves. Journal of Animal Science 73, 373-380.

Pinto LFB, Ferraz JBS, Meirelles FV, Eler JP, Rezende FM, Carvalho ME, Almeida HB, Silva RCG (2010) Association of SNPs on CAPN1 and CAST genes with tenderness in Nellore cattle. Genetics and Molecular Research 9(3), 1431-1442. doi:10.4238/vol9-3gmr881

Pringle TD, Williams SE, Johnson DD, West RL (1997) Carcass characteristics, the calpain proteinase system, and aged tenderness of Angus and Brahman crossbred steers. Journal of Animal Science 75, 2955-2961.

Ribeiro E, Hernandez J, Zanella E, Shimokomaki M, Prudencio-Ferreira S, Youssef E, Ribeiro H, Reeves J (2005) Weight and carcass characteristics of Poll Nellore, Guzerat-Poll Nellore and Brahman-Poll Nellore steers. Journal of Animal Science 83, 265-269. 
Riley DG, Chase CC Jr, Coleman SW, Olson TA (2007) Evaluation of birth and weaning traits of Romosinuano calves as purebreds and crosses with Brahman and Angus. Journal of Animal Science 85, 289-298. doi:10.2527/jas.2006-416

Schutt KM, Burrow HM, Thompson JM, Bindon BM (2009a) Brahman and Brahman crossbred cattle grown on pasture and in feedlots in subtropical and temperate Australia. 1. Carcass quality. Animal Production Science 49, 426-438. doi:10.1071/EA08081

Schutt KM, Burrow HM, Thompson JM, Bindon BM (2009b) Brahman and Brahman crossbred cattle grown on pasture and in feedlots in subtropical and temperate Australia. 2. Meat quality and palatability. Animal Production Science 49, 452-460. doi:10.1071/EA08083

Shackelford SD, Morgan JB, Cross HR, Savell JW (1991) Identification of threshold levels for Warner-Bratzler shear force in beef top loin steaks. Journal of Muscle Foods 2, 289-296. doi:10.1111/j.1745-4573.1991. tb00461.x

Shackelford SD, Wheeler TL, Koohmaraie M (1995) Relationship between shear force and trained sensory panel tenderness ratings of 10 major muscles from Bos indicus and Bos taurus cattle. Journal of Animal Science 73, 3333-3340.
Silva JA, Patarata L, Martins C (1999) Influence of ultimate $\mathrm{pH}$ on bovine meat tenderness during ageing. Meat Science 52, 453-459. doi:10.1016/ S0309-1740(99)00029-7

Smith T, Domingue JD, Paschal JC, Franke DE, Bidner TD, Whipple G (2007) Genetic parameters for growth and carcass traits of Brahman steers. Journal of Animal Science 85, 1377-1384. doi:10.2527/jas.2006-653

Thallman RM, Cundiff LV, Gregory KE, Koch RM (1999) Germplasm evaluation in beef cattle - Cycle IV: postweaning growth and puberty of heifers. Journal of Animal Science 77, 2651-2659.

Turner JW (1980) Genetic and biological aspects of Zebu adaptability. Journal of Animal Science 50, 1201-1205.

USDA (1999) 'Official United States standards for grades of carcass beef.' Agric. Marketing Serv. (USDA: Washington, DC)

Wheeler TL, Savell JW, Cross HR, Lunt DK, Smith SB (1990) Mechanisms associated with the variation in tenderness of meat from Brahman and Hereford cattle. Journal of Animal Science 68, 4206-4220.

Wheeler TL, Cundiff LV, Shackelford SD, Koohmaraie M (2001) Characterization of biological types of cattle (Cycle V): Carcass traits and longissimus palatability. Journal of Animal Science 79, 1209-1222. 